\title{
Problem hydromorphic soils in north-east Thailand. \\ 3. Saline-acid conditions, reclamation, improvement and management
}

\section{Robert Brinkman ${ }^{1}$ and P. J. Dieleman ${ }^{2}$}

1 Department of Soil Science and Geology, Agricultural University, Wageningen, the Netherlands

${ }^{2}$ Land and Water Development Division, Food and Agriculture Organization, Rome, Italy

Accepted: 28 March 1977

Key words: paddy soils, aluminium toxicity

\section{Summary}

Saline-acid conditions have developed in patches in the irrigated areas on the low terrace in north-east Thailand. There are also traditionally uncultivated, virtually barren, saline-acid strips adjoining higher terrace remnants, in spite of the excess of monsoon rainfall over evapotranspiration. Calculations show that the salts in the shallow groundwater of the low terrace may have originated from rainfall, but that salts in the main rivers are mainly derived from salt beds.

The local surface salinity, mainly of $\mathrm{NaCl}$, is caused by continual evapotranspiration during the dry season and locally impeded leaching. The latter is due to a combination of a shallow water-table, slow vertical permeability and in some cases the slight elevation above the normal level of monsoon flooding.

The high salt concentrations in and on the soil surface bring originally exchangeable aluminium into solution, which lowers the $\mathrm{pH}$. Soluble aluminium is toxic to plant roots even at low concentrations. In extreme cases even some ferric iron is dissolved at the soil surface.

Reclamation, improvement and management practices on these soils should include leaching, for example under two rice crops per year; judicious liming, to eliminate most of the exchangeable aluminium but not to exceed the small buffer capacity of these soils; and emphasis on paddy rice, both in the monsoon season and irrigated in the dry season.

If, however, dry-season dryland crops are to be grown, physical problems of different kinds may necessitate further land improvement and management practices. These include, principally, lowering and keeping down the water-table, for example by control of irrigation water losses from canals and ditches; ploughing or disking in chopped crop residues with added nitrogen; and locally, chiseling the upper part 
of a dense subsurface horizon. Wherever salts and toxicity have not been eliminated by reclamation, the procedure of sowing in the sloping sides of ridges as early as possible in the dry season would protect the seedlings from salinity and aluminium toxicity, since irrigation would force the salts to the ridge tops, away from the young plants.

\section{Introduction}

In the rice-growing plains of north-east Thailand there are scattered small spots and strips of traditionally uncultivated, apparently saline, virtually barren land. In an experimental dry-season irrigation project in the area, extensive salinity and

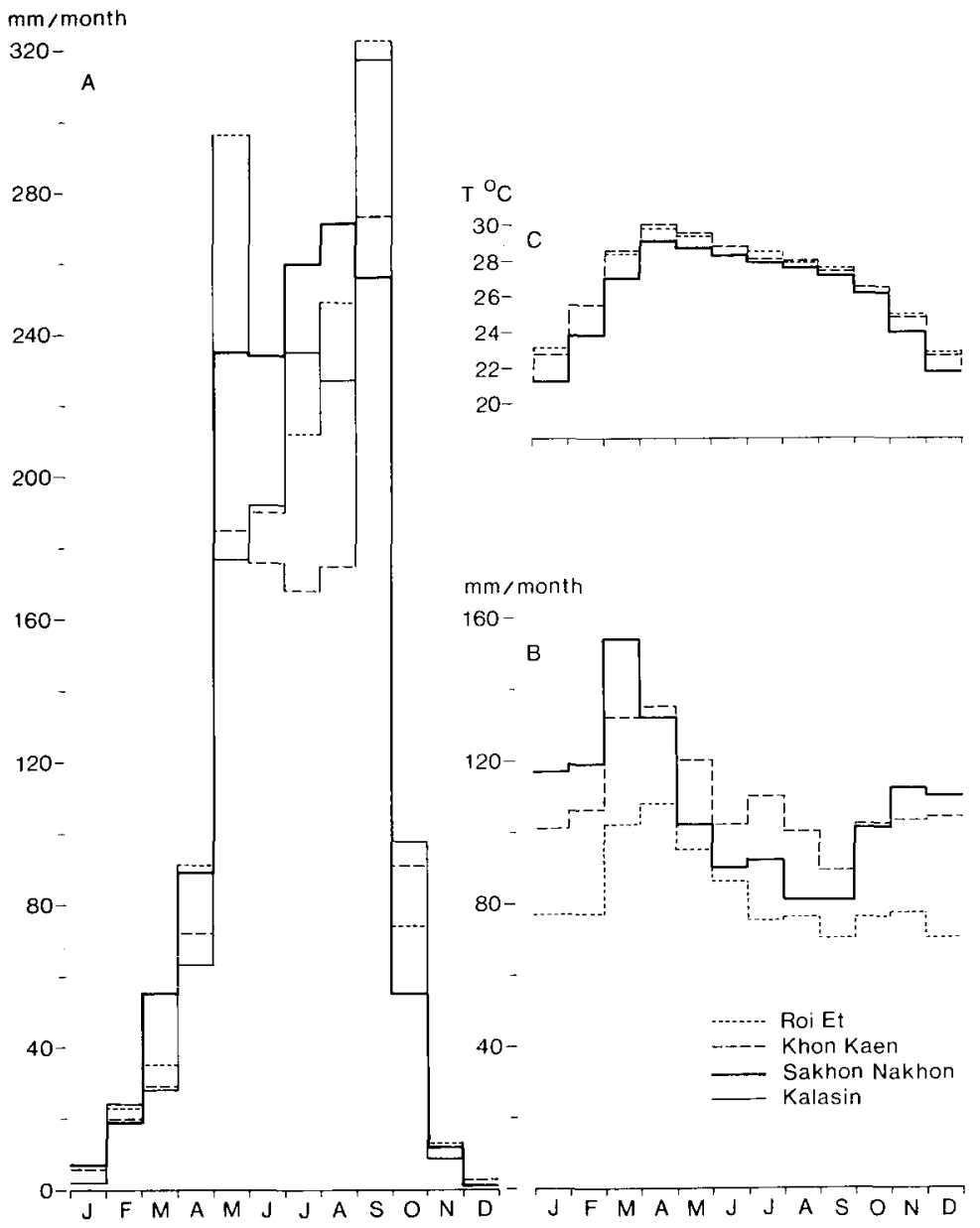

Fig. 1. A: monthly rainfall; B: potential evapotranspiration; C: temperature at three stations around Kalasin. Data recalculated from van den Eelaart (1972) and Wernstedt (1972). 


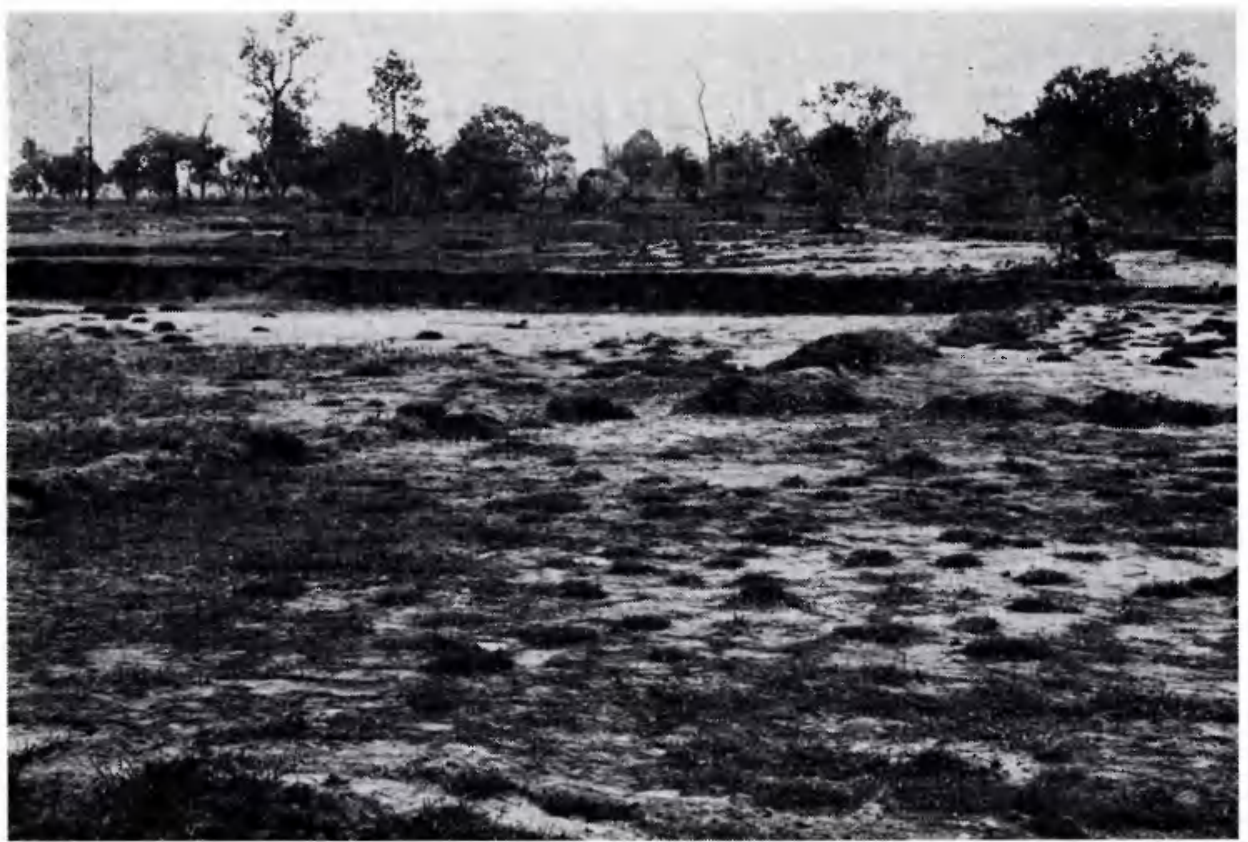

Fig. 2. Virtually barren, abandoned fields with saline-acid surface along the margin of a slight rise (background) in the low terrace.

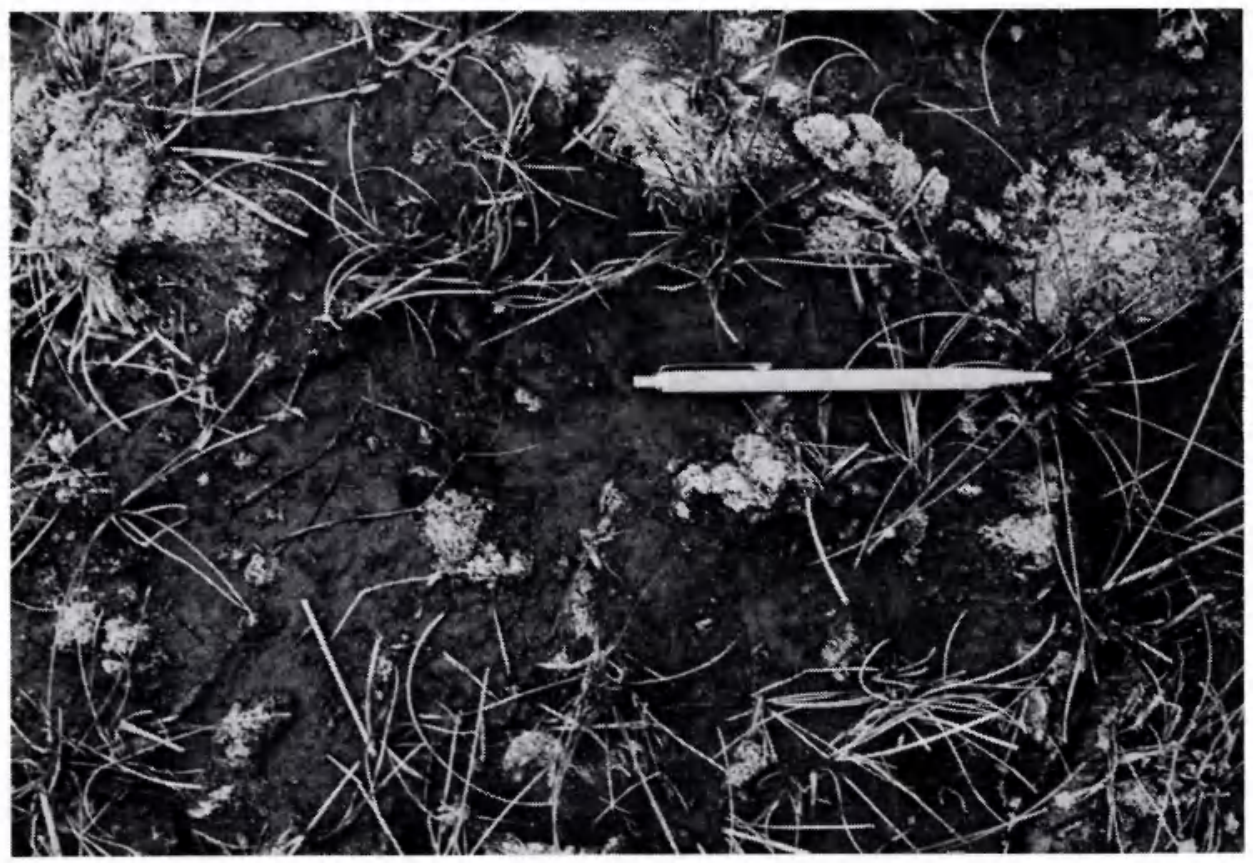

Fig. 3. Saline-acid surface of virtually barren field. Pencil $14 \mathrm{~cm}$ long. 
waterlogging hampered cultivation and lowered productivity. These problems were investigated during a short field study near Kalasin (Muang district). The environment and the main rice-growing soil of the area is described, and its genesis discussed, in companion papers (Brinkman et al., 1977; Brinkman, 1977). The present paper reports on the saline and saline-acid conditions encountered, discusses mechanisms of accumulation of sodium, calcium and toxic soluble aluminium salts, describes the range of problem soils caused by and encountered during the development of dry-season irrigation, and discusses means for their efficient reclamation and use.

\section{Climate}

Rainfall is extremely seasonal (Fig. 1A). More than 80 per cent of the annual total of $1400 \mathrm{~mm}$ falls in the five months May-September, and about 3 per cent in November-February. The mean annual temperature is about $26{ }^{\circ} \mathrm{C}$, the coldest month is January $\left(22^{\circ} \mathrm{C}\right)$ and the hottest month April $\left(30^{\circ} \mathrm{C}\right)$, just before the start of the monsoon rains (Fig. 1C). Potential evapotranspiration is about $100 \mathrm{~mm} /$ month, with a maximum in March or April (Fig. 1B). The excess monsoon rainfall over potential evapotranspiration (May-September) is about $700 \mathrm{~mm}$, the excess potential evapotranspiration over rainfall in the dry season (October-April) is $500 \mathrm{~mm}$.

\section{Land use}

The dominant land use on the extensive, fine-loamy low terrace is paddy rice cultivation on the rain-water flooded land in summer, and fallow in winter. There are few scattered high trees, which survive the seasonal flooding with no apparent ill effects. Traditionally uncultivated, virtually barren areas (Fig. 2, 3) typically occur along the higher margins of the low terrace, adjoining outcrops of higher, more sandy, still older terrace remnants; and locally on slight rises in the low terrace. Fig. 4 is a schematic cross-section of these landforms. Non-saline, iron-rich perennial seepage strips with a grass and sedge cover were seen in a low part of the low terrace adjacent to a large area of sandy high terrace. The high terrace remnants

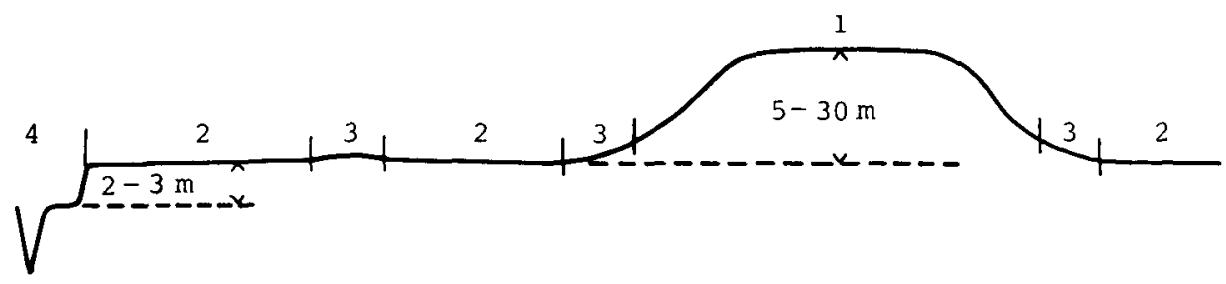

Fig. 4. Schematic cross-section near Kalasin.

1) Sandy, high terrace remnant.

2) Normal, non-saline low terrace including recently waterlogged and salinized parts.

3) Saline-acid, virtually barren higher patches and margins, part with perennially high watertable.

4) Recent river valley. 
PROBLEM HYDROMORPHIC SOILS IN NORTH-EAST THAILAND. 3

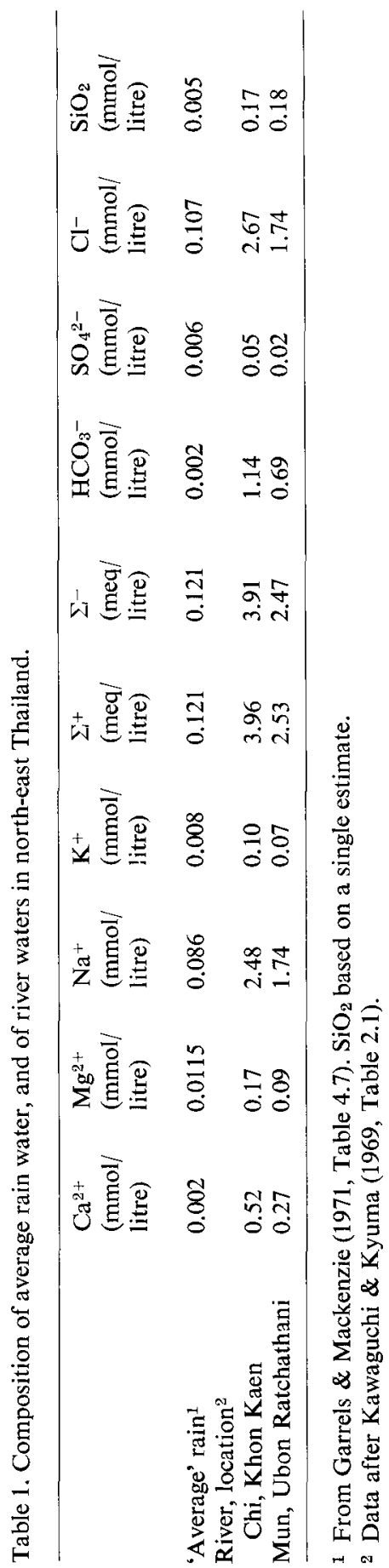

Neth. J. agric. Sci. 25 (1977) 
originally were forested, and many are at present under dryland cultivation of various crops or under bush fallow.

Dry-season irrigation projects have started, which use river water impounded by large and small dams. Pilot experiments were made with several dryland crops, irrigated by basin and furrow methods, on land used for paddy rice in the monsoon season.

\title{
Regional salt balance
}

During and just after the monsoon season, when the soils are wet, the average actual

Table 2. Cation exchange characteristics and composition of soil extracts in non-saline, recently salinized, and

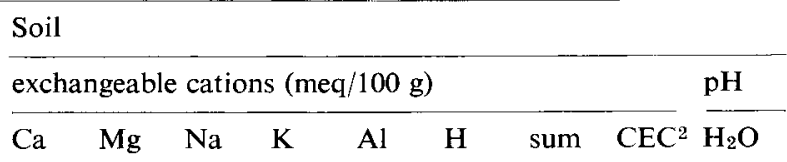

A. Non-saline area.

Main observation pit (Brinkman et al., 1977)

$16-26 \mathrm{~cm}$

$0.5 \quad 0.0$

$\begin{array}{lll}0.1 & 1.0 & 0.6\end{array}$

$0.3 \quad 1.6$

2.1

4.7

96-140 cm

$0.3 \quad 0.0$

$0.1 \quad 0.1$

4.3

$0.3 \quad 5.1$

$6.1 \quad 4.5$

Location 761-241, table IV-9

( summarized from USBR, 1971)

$0-18 \mathrm{~cm}$

$120-190 \mathrm{~cm}$

$\begin{array}{lll}0.5 & 0.5 & 0.0\end{array}$

$\begin{array}{lll}0.4 & 0.2 & 1.6\end{array}$

5.2

$\begin{array}{lll}2.2 & 0.6 & 2.7\end{array}$

$\begin{array}{lll}0.1 & 0.3 & 5.9\end{array}$

5.6

Location 855-744, table IV-10

$\begin{array}{lll}1.2 & 1.4 & 0.0\end{array}$

$\begin{array}{lll}0.4 & 0.2 & 3.2\end{array}$

6.1

$14-23 \mathrm{~cm}$

$\begin{array}{lll}2.8 & 1.9 & 0.0\end{array}$

$\begin{array}{lll}0.7 & 0.1 & 4.5\end{array}$

5.9

B. Area salinized due to recent high water-table.

Ridge with failing mung-beans;

crest of ridge, upper few millimetres

(field measurement)

Upper $3 \mathrm{~cm}$ of ridge

Base of ridge, $5-15 \mathrm{~cm}$ depth

'White substance'

'Black substance'

C. Traditionally uncultivated, saline area.

White crust with some soil

material

$1 \mathrm{~cm}$ soil below white crust

Black surface with rusty efflorescence, with $3 \mathrm{~mm}$ soil material

\author{
0.7
}

with 3 mm soil material

1 Saturation extract in samples from USBR (1971); $1: 2$ soil:water extract in other samples.

2 CEC: cation exchange capacity.

3 Approximate values from conductivity data.

4 Not determined dependably because of great excess of soluble sodium.

Neth. J. agric. Sci. 25 (1977) 
evapotranspiration from rice fields, forests and upland crop areas is probably about equal to the potential evapotranspiration. After the end of November, however, from the second month of the dry season onwards, the actual evapotranspiration is probably limited to the amount of rainfall. We therefore may add the potential evapotranspiration May-November and rainfall December-April to estimate the actual annual evapotranspiration: about $800 \mathrm{~mm}$. Total annual rainfall is about $1400 \mathrm{~mm}$; net excess rainfall would therefore be about $600 \mathrm{~mm}$. The concentration of cyclic salts in rivers draining the area would then amount to about $2.3(1400 / 600)$ times the concentration in rain water. We have assumed an average composition

traditionally saline, barren areas of the low terrace near Kalasin, north-east Thailand.

\begin{tabular}{|c|c|c|c|c|c|c|c|c|c|c|c|c|c|}
\hline \multirow[b]{3}{*}{$\begin{array}{l}\mathrm{CaCl}_{2} \\
(0.01 M)\end{array}$} & \multirow[b]{3}{*}{$\begin{array}{l}\mathrm{KCl} \\
(1 M)\end{array}$} & \multicolumn{12}{|c|}{ Soil extract ${ }^{1}$} \\
\hline & & \multicolumn{10}{|c|}{ soluble salts (meq/litre) } & \multirow[t]{2}{*}{$\mathrm{pH}$} & \multirow{2}{*}{$\begin{array}{l}\text { total } \\
\text { salts } \\
(\mathrm{g} / \mathrm{l})^{3}\end{array}$} \\
\hline & & $\mathrm{Ca}$ & $\mathrm{Mg}$ & $\mathrm{Na}$ & $\mathbf{K}$ & $\mathrm{Fe}$ & $\mathrm{Al}$ & sum $^{+}$ & \multicolumn{2}{|c|}{$\mathrm{HCO}_{3} \mathrm{Cl}$} & $\mathrm{SO}_{4}$ & & \\
\hline 3.9 & & 0.0 & 0.0 & 0.5 & 0.0 & 0.0 & 0.0 & 0.5 & 0.0 & 0.6 & $0.01-$ & 5.0 & 0.03 \\
\hline \multirow[t]{2}{*}{3.7} & & 0.0 & 0.0 & 0.5 & 0.0 & 0,0 & 0.0 & 0.5 & 0.0 & 0.6 & \multirow{2}{*}{$\begin{array}{l}0.00+ \\
0.0\end{array}$} & 4.8 & 0.03 \\
\hline & & 0.0 & 0.0 & 1.1 & 0,0 & 0.0 & 0.0 & 1.1 & 0.0 & 1.1 & & 6.3 & 0.06 \\
\hline 4.9 & 3.9 & 2.0 & 0.2 & 4.2 & 0.2 & & & 6.6 & & & & & 0.4 \\
\hline 5.4 & 4.2 & 0.5 & 0.5 & 8.7 & 0.0 & & & 9.7 & & & & & 0.6 \\
\hline 5.0 & 4.4 & 1.0 & 0.0 & 0.4 & 0.1 & & & 1.5 & & & & & 0.08 \\
\hline 4.6 & 3.9 & 0.5 & 0.0 & 0.4 & 0.0 & & & 0.9 & & & & & 0.05 \\
\hline 4.9 & & 32 & 9 & 8 & 13 & 0 & 0 & 62 & 0 & 36 & 33 & 5.5 & 4 \\
\hline 5.0 & & 1 & 1 & 1 & 2.5 & 0 & 0 & 5.5 & 0 & 2.5 & 1 & 5.6 & 0.3 \\
\hline 5.1 & & 46 & 9 & 40 & 10 & 0 & 0 & 105 & 2 & 41 & 77 & 5.5 & 7 \\
\hline 6.2 & & 12 & 1 & 14 & 13 & 0 & 0 & 40 & 1 & 48 & 3 & 7.1 & 3 \\
\hline 3.6 & 3.6 & 14 & 3 & 3575 & 2 & 0 & 8 & 3602 & 0 & 3600 & 6 & 3.5 & 200 \\
\hline 3.6 & 3.6 & 15 & 8 & 335 & 1 & 1 & 15 & 375 & 0 & 340 & 1 & 3.6 & 20 \\
\hline 3.8 & 3.8 & 14 & 7 & 230 & 1 & 14 & 5 & 271 & 0 & 270 & 2 & 3.0 & 15 \\
\hline
\end{tabular}


of rain-water, because data on salt concentrations in rain-water for north-east Thailand were not available to us. Even though calculations based on these assumptions are necessarily crude, it is clear from Table 1 that most of the salts in the Chi and Mun rivers are derived from other sources than rain. The dominant salts, $\mathrm{NaCl}$ and $\mathrm{CaCO}_{3}$, probably originate from salt beds in the substratum of the plains (near Chaiyaphum from 60-70 m below surface, Takaya, 1974) and from limestone in the hill ranges on their western border, respectively. $\mathrm{Mg}, \mathrm{K}$ and silica were probably contributed by the weathering of silicate minerals.

The sulphate concentrations, however, are in the range expected from rainfall alone. This last point indicates that the acidity and aluminium toxicity in the area, discussed below, do not originate from oxidation of pyrite, as in the acid sulphate soils of the central plain in Thailand or of the Mekong delta.

\section{Local salt balance}

The low terrace, which comprises very large, nearly level areas, lies above local river levels, and it would seem unlikely that salts from the rivers or from the deep groundwater would reach the shallow groundwater of the terrace soils. In the central part of the plain, however, near the Chi and between the Chi and Mun rivers, Takaya (1974) found that of the 27 wells to $15-20 \mathrm{~m}$ depth reported in or near the area underlain by the Salt Formation, about half are fresh, half are brackish or saline. Also, in half of the 18 boreholes he examined there are beds within $3 \mathrm{~m}$ of the surface that contain (little) chloride, for example near Khon Kaen and downstream (south) of Kalasin.

One hypothesis would be that the salts in the shallow groundwater would have been derived from former local salt beds. This would imply that there would have been virtually no through leaching, and that almost all of the net excess rainfall would have been removed over the soil surface. An alternative hypothesis would be that salts in the shallow groundwater may have been derived from remnants of salt in near-surface beds of the Salt Formation somewhere upstream (Sinanuwong \& Takaya, 1974a, b). This would require lateral subsurface movement of saltcontaining water over distances of at least several kilometres through a nearly level, seasonally flooded area without appreciable additions of monsoon rainfall on top of the groundwater. Neither of these hypotheses would explain the locally high sulphate contents found with the chloride in recently salinized patches (Table $2 \mathrm{~B}$ ).

A third hypothesis is that cyclic salts brought in by rain-water have accumulated in the shallow groundwater. This would explain the presence of sulphates in the salts at the surface. The groundwater at $1.6 \mathrm{~m}$ depth at the main site studied by us contains about $1.1 \mathrm{mmol} \mathrm{NaCl} /$ litre, whereas the soil solution would contain about $0.3 \mathrm{mmol} /$ litre if all of the $600 \mathrm{~mm}$ net excess rainfall would leach through the soil. A concentration of $1.1 \mathrm{mmol}$ salt/litre in the shallow groundwater could be explained by cyclic salts if only about $100 \mathrm{~mm}$ would leach through the soil annually. (This would imply lateral removal over the soil surface of about $500 \mathrm{~mm}$ of the monsoon rainfall.) With $800 \mathrm{~mm}$ total evapotranspiration, as estimated above, the concentration in the groundwater would then be 9 times that in average rainwater. However, an exclusively cyclic origin of the salts would not explain why the 
chloride/sulphate ratio in the groundwater seems to be higher than in average rainwater.

Both rain and salt beds may therefore have contributed to the salts in the shallow groundwater. Irrespective of the origin of the salts, the data indicate that even in the non-saline low terrace areas, much of the monsoon rainfall is removed laterally over the surface and that net downward leaching through the soil is small, about $100 \mathrm{~mm}$ or less per year. Data on saturation extracts in two other profiles of Roi Et series, summarized from USBR (1971) in Table 2A, also show salinity levels in excess of $0.3 \mathrm{meq} /$ litre throughout the profiles and up to about $4 \mathrm{meq} /$ litre in some horizons. The highest of these salinity levels appear to be correlated with the presence of very slowly permeable horizons.

\section{Saline-acid (aluminous) conditions}

The normal, non-saline soils have considerable exchangeable aluminium and a low $\mathrm{pH}\left(\mathrm{H}_{2} \mathrm{O}\right)$, but no soluble aluminium (Table $2 \mathrm{~A}$ ), as long as they are not fertilized. With large fertilizer applications, the total salt concentration rises and the soil $\mathrm{pH}$ drops (compare the $\mathrm{pH}$ in water, in $\mathrm{CaCl}_{2} 0.01 M$ and in $\mathrm{KCl} 1 M$, Table $1 \mathrm{~A}$ ). Where exchangeable aluminium exceeds about $40 \%$ of the effective cation exchange capacity, sufficient soluble aluminium may then be displaced from the exchange complex by the fertilizer cations to cause toxic conditions for the crop.

\section{Areas salinized due to a recent high water-table}

In an experimental area recently provided with dry-sason irrigation water, the dryseason water-table had risen to less than half a metre below surface in some parts. Small areas were still waterlogged, with shallowly inundated patches (Fig. 5), when observed in the late dry season (March 1972). The rise in water-table appeared to be due mainly to losses in the distribution system (distributaries and field ditches) aggravated by the absence of an effective drainage system. (Seepage from the nearby reservoir, and from elsewhere, may also have had some effect.) The scattered high trees in the area with the recent perennially high water-table did poorly or were dying, possibly due to lack of oxygen in the root zone.

In this area, considerable problems were encountered in dry-season cultivation of irrigated dryland crops, especially with germination. Soil salinity within the crests of planting ridges was moderate, as illustrated in Table $2 \mathrm{~B}$. Thin salt crusts locally on the ridge crests, the absence even of weeds on the crests and their presence on the ridge flanks indicated that surface salinity may have been high, however. The soil extracts from samples taken at $0-3 \mathrm{~cm}$ and $5-15 \mathrm{~cm}$ depths in a ridge planted with mung beans show no soluble aluminium, but the field measurement of a $\mathrm{pH}$ less than 3 in the strongly saline upper few millimetres suggests that local aluminium toxicity may be present, aggravating the effects of the salinity.

Not only dryland crops, but also the early stages of paddy rice may be affected by aluminium toxicity. Urieli (pers. comm.) encountered failure of rice seedlings planted in a recently inundated field. In contrast, he found good growth of replacement seedlings planted a few weeks later in the same field that had been kept under 


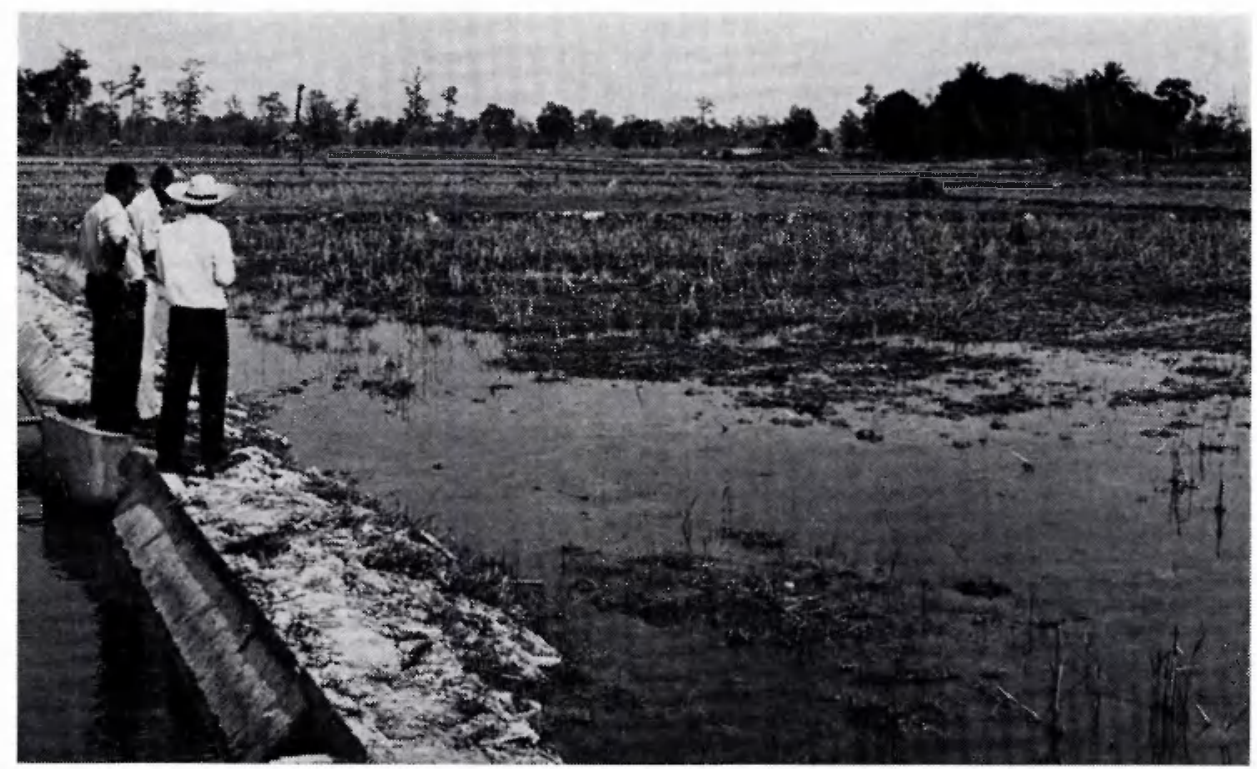

Fig. 5. Waterlogged and partly inundated field in irrigation area, with salt accumulation on field bunds especially along concrete-lined irrigation ditch.

water, presumably after progressive reduction had eliminated the toxic aluminium.

Not all white material seen at the surface in recently salinized areas is necessarily acid or harmfully saline. The analysis of the soil extract from the upper part of the ridge shows mainly gypsum, and the same applies for the white substance taken from the surface in another waterlogged area (Table 2B). The extract of a black substance scraped from the surface in a similar area shows that calcium chloride may also be present locally.

\section{Traditionally uncultivated, saline areas}

In the virtually barren parts of the slightly higher margins and rises of the low terrace, surface salinity is very high and $\mathrm{NaCl}$ is the dominant salt (Table 2C). In the extracts, contents of soluble $\mathrm{Ca}, \mathrm{Mg}, \mathrm{K}$ and $\mathrm{SO}_{4}$ are similar to those in the recently salinized areas. In addition, however, toxic concentrations of soluble aluminium, and in some cases iron, are present in the salt crust as well as in the soil immediately below.

These virtually barren sites are not flooded in the rainy season and rain-water disappears mainly by surface runoff. At the same time, the adjacent main expanse of the low terrace is flooded, and the water-table in the margins and rises is very high. During the dry season, the water-table slowly drops in some of these sites. In others, it is perennially high due to lateral seepage from the adjacent higher, more sandy terrace remnants. 


\section{Interpretation}

The mechanisms causing the different saline, acid and toxic conditions may be summarized as follows.

In the extensive level, non-saline low terrace, the soil solution leaching through during the rainy season is very dilute, so that cation exchange strongly favours ions of higher valence. The cations in the non-saline groundwater are dominantly $\mathrm{Na}$, therefore, most of the $\mathrm{Ca}, \mathrm{Mg}$ (and probably $\mathrm{K}$ as well) from the rain-water being retained in exchangeable form.

Where the water-table remains high during the dry season, capillary rise and evaporation of groundwater causes an increase in concentration and upward movement of $\mathrm{NaCl}$ through the soil profile. At high concentrations in solution, sodium is a relatively effective displacing agent for exchangeable potassium and divalent ions and, at very high concentrations, for trivalent aluminium as well.

In the recently salinized area, cation exchange during the passage of the salt causes the appearance of some calcium, magnesium and potassium in solution. As long as the salinity is not extreme, aluminium remains exchangeable and does not appear in solution. The salts appearing at the surface are mixed, therefore, $\mathrm{Ca}, \mathrm{Mg}$

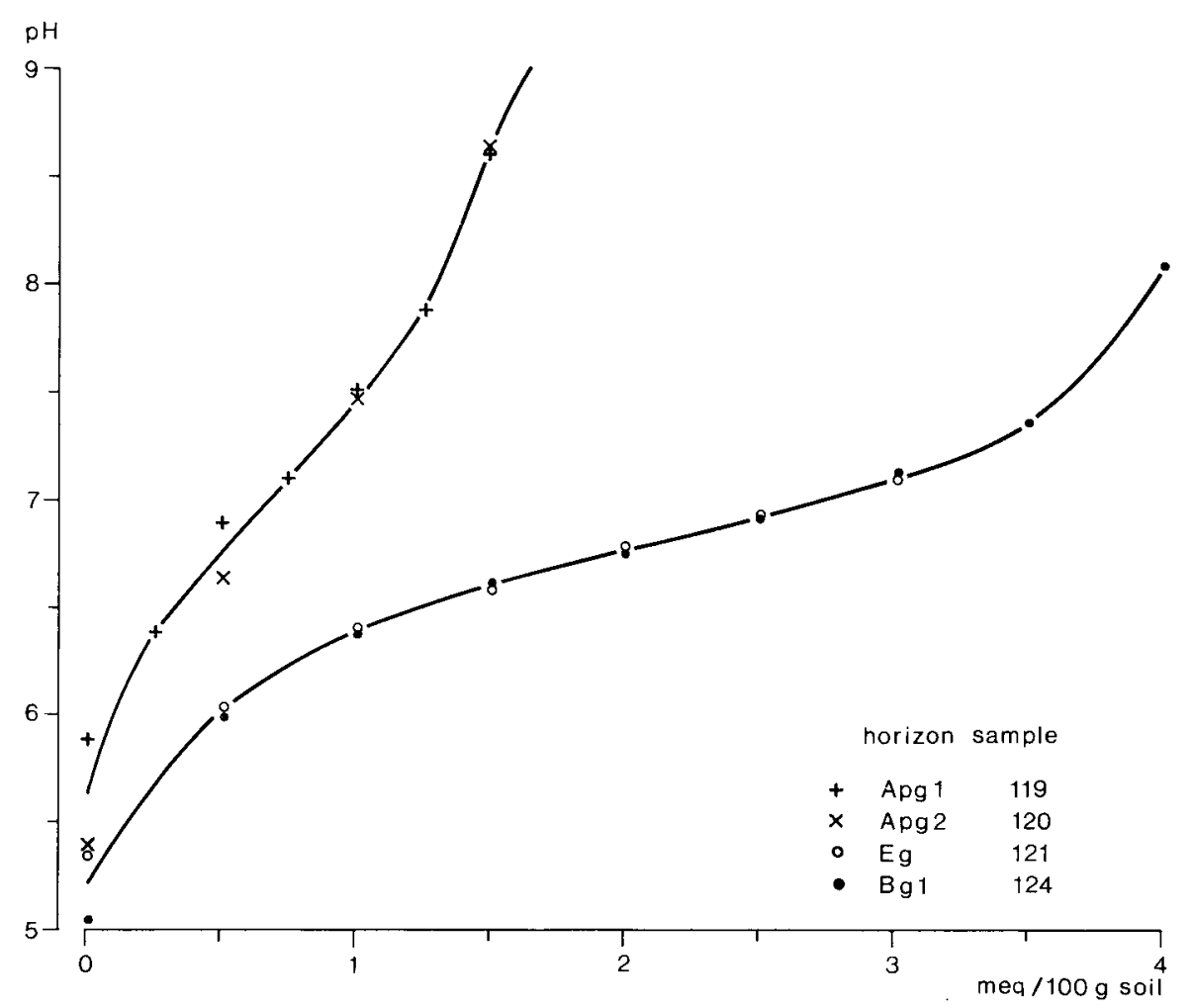

Fig. 6. Slow titration curve of $\mathrm{Apg}, \mathrm{Eg}$ and $\mathrm{Bg} 1$ horizons. $48 \mathrm{~h}$ equilibration of $1 \mathrm{~g}$ soil in $10 \mathrm{ml}$ solution, between 0 and $4 \mathrm{mmol} \mathrm{NaOH} /$ litre. 
and $\mathrm{K}$ originating mainly from the exchange complex and $\mathrm{Na}$ from the groundwater. Only locally at the surface, where salt concentrations are very high, the extreme acidity suggests the presence of soluble aluminium in addition.

The presence of sulphate besides chloride is probably due to its occurrence in the groundwater in concentrations less than $0.1 \mathrm{meq} /$ litre. The non-saline soil contains less than $0.01 \mathrm{meq}$ sulphate/litre.

In the traditionally uncultivated, saline area, some exchangeable aluminium and hydrogen are brought into solution by the very high concentrations of soluble sodium. With further evaporation these, too, are concentrated and brought to the surface. The resulting extreme acidity causes the appearance of soluble ferric iron by dissolution of free iron oxides.

The calcium, magnesium and potassium concentrations in the extracts remain of the same order of magnitude with about a thousandfold increase in sodium chloride concentration, suggesting that their exchange from the soil horizons by sodium may be largely complete even after a few years of salinization. Precipitation of gypsum on high spots in the area may have kept the sulphate concentration from rising further with the rise in chloride concentration. No crystalline iron or aluminium sulphates were observed in X-ray diffraction photographs of even the most saline acid samples, and extracts are undersaturated with respect to $\mathrm{Fe}$ and $\mathrm{Al}$ sulphates. The extract of the black surface with rusty efflorescence is in equilibrium with amorphous ferric hydroxide. (Activity corrections for these estimates were made by the mean salt method, with the use of coefficients from tables in Robinson \& Stokes, 1968; solubility and dissociation constants used were from van Breemen, 1973, and Vlek et al., 1974.)

\section{Reclamation, improvement and management}

\section{Chemical aspects}

Liming can eliminate the hazard of aluminium toxicity in non-saline surface soils. Applications of the order of 1 tonne $\mathrm{CaCO}_{3}$ per hectare ploughed layer $\left(2 \times 10^{6}\right.$ $\mathrm{kg}$ ) would neutralize a large part of the exchange acidity, which ranges from 0.6 to $1.6 \mathrm{meq} / 100 \mathrm{~g}$ soil in the surface soils measured. A slow titration experiment was done on the ploughed horizon, ploughpan and two lower horizons of the soil at the main observation site, an example of Roi Et series (Fig. 6). This shows that the surface horizons are neutralized with $1 \mathrm{meq}$ base $/ 100 \mathrm{~g}$ soil, and the deeper horizons with $3 \mathrm{meq} / 100 \mathrm{~g}$. Buffering is very poor: with $1.5 \mathrm{meq}$ base $/ 100 \mathrm{~g}$, the surface soil has a $\mathrm{pH}$ value above 8.5 . There is a danger of over-liming, therefore, with probably ill effects on the availability of trace elements, such as zinc, and on the physical stability of the soils. Under-liming is safer than over-liming: once the exchangeable aluminium is less than about $40 \%$ of the effective cation exchange capacity, no toxic concentrations of soluble aluminium need be expected even with relatively large fertilizer applications.

Liming as a possible remedy for extreme acidity and toxic concentrations of soluble aluminium (and iron) in saline surface soils should be considered with caution. Liming alone would not eliminate the strong surface salinity which is 
another cause of poor germination and growth of the irrigated crops in the dry season.

The surface salts in the recently salinized area could be removed by leaching, e.g. under rice cultivation, if the water-table in (open) drains would be kept low for as long a period as possible each year.

During leaching under inundation, either naturally in the rainy season or by surface irrigation, sodium salt concentrations decrease by probably several orders of magnitude. At these lower concentrations, sodium has a very low displacing efficiency for calcium and aluminium, so that especially the soluble aluminium will be adsorbed in the upper horizons during leaching of the salt. This may result in exchange acidities about twice those in the nonsaline soils, even after leaching.

For dryland crops, liming would be necessary to eliminate the aluminium toxicity caused by the very high exchange acidity in leached, formerly strongly saline soils even at low fertilizer concentrations. An initial application of 1 tonne lime/ha can be given in any case; further amounts of lime needed could be estimated by slow titration to $\mathrm{pH} 7$, either by $\mathrm{pH}$ meter or by indicator solution. As in the case of non-saline soils, excess lime is expected to be harmful.

If dry-season dryland crops are to be grown in an area still containing acid salts, the crops should be sown as early as possible in the dry season, on the side instead of on top of ridges. Fertilizers should also be applied at the side of the ridges, and irrigation water levels during the first weeks after sowing should be carefully controlled to reach above the level of sowing but not above the tops of the ridges. This would tend to concentrate the salt and soluble acid in the surface of the ridge crests, away from the plants. Although this may be a new procedure for saline-acid conditions, it is a normal recommended method in saline or saline-sodic areas (Kovda et al., 1973, p. 327; Ayers \& Westcot, 1976, p. 43-46).

For paddy rice, grown under natural inundation by monsoon rainfall or irrigated in the dry season, liming does not appear essential if seedlings are planted more than about two weeks after the start of inundation. After that time, microbial decomposition of organic matter left by the previous crop or vegetation will normally have reduced sufficient ferric oxides to ferrous compounds to eliminate the aluminium toxicity hazard. During iron reduction, hydrogen ions are consumed and part of the aluminium is hydrolysed and immobilized for the duration of the reducing conditions.

\section{Physical aspects}

Crops are at present being grown under rather unfavourable water-table conditions. Normally, the water-table should remain below the plant root zone and, to effect such a condition, a permanent system of deep drains would be necessary. Such a system, however, would require a considerable investment which may not be justified at the present time, when dryland cropping, as an alternative, may still be concentrated on the better drained soils of the higher terrace. Irrigation projects on the low terrace may then be assigned to double cropping of paddy rice.

If, however, it is considered necessary to develop the different soils of the low terrace for irrigated dryland cropping besides monsoon-season rice, the following 
set of recommendations may be helpful.

The water-table fluctuations may be partially controlled and the normal watertables maintained at 50-60 cm below surface if the surface drains would be deepened to about $70 \mathrm{~cm}$. The specific technical conditions that favour such a provisional solution are the high quality irrigation and groundwater which minimise the danger of salinity; the relatively low evaporation rates; the seeding on ridges; and the occurrence of a more or less compact soil layer at shallow depth that helps reduce deep percolation losses. The deepened surface drains could be given steep side slopes ( 2 to $3: 1$ ) to avoid land losses, but this entails that the drains will need to be partially re-dug each year at the beginning of the dry season.

The land should be cultivated in dry condition whenever possible, and while the water-table is at least about $0.5 \mathrm{~m}$ below the surface. One application of 500 to $1000 \mathrm{~kg} \mathrm{CaCO}$ per hectare should be given before ploughing. This could be repeated once after 2 or 3 years; no further lime should be applied generally except after estimation of lime requirement of specific areas. Instead of the traditional burning, chopped crop residues may be disked or ploughed in to shallow depth after broadcasting about $1 \mathrm{~kg} \mathrm{~N}$ per $40 \mathrm{~kg}$ of estimated dry weight of the crop residues. This is expected to raise the stability of the surface soil material. No subsoil material should be brought to the surface, because this contains a generally larger proportion of potentially toxic aluminium than the ploughed layer, and because the subsoil below the ploughpan appears to be generally porous and stable when undisturbed.

For specific kinds of problem soils identified below, the following individual recommendations apply in addition to the above.

On all non-saline land with groundwater at or near the surface at any time during the dry season or at a depth less than $0.5 \mathrm{~m}$ at the time of land preparation, either one or two successive rice crops per year may be grown until the groundwater table has gone down by control of irrigation water losses or the establishment of a drainage system or both. Land that is perennially wet due to seepage from adjacent higher areas is best left in its present state.

On other non-saline land with a dense, unstable, very slowly permeable ploughed horizon with a slaked surface, two successive rice crops could be grown with dry cultivation without puddling, and with ploughing in of chopped crop residues and added nitrogen, until the stability of the surface has been improved.

On other non-saline land with a dense, very slowly permeable subsoil horizon extending deeper than the usual thin ploughpan, the depth of this horizon should be estimated in a pit when the soil is moist or dry, or by penetrometer when the soil is wet. The upper part can then be chiselled when the soil is dry; a part should be left intact to minimize water losses under rice. Mixing in about 1 tonne $\mathrm{CaCO}_{3}$ per hectare for every $20 \mathrm{~cm}$ chiselled below the normal ploughing depth would probably increase the effect.

\section{Acknowledgments}

We thank FAO for their permission to publish this paper; Messrs L. Th. Begheyn and J. R. M. Huting for the analyses listed in Table 2; and Prof. Dr L. J. Pons and 
Dr W. J. van Liere for their extensive constructive comments on a draft.

\section{References}

Ayers, R. S. \& D. W. Westcot, 1976. Water quality for agriculture. Irrigation and Drainage Paper 29. FAO, Rome, 97 pp.

Breemen, N. van, 1973. Calculation of ionic activities in natural waters. Geochim. cosmochim. Acta 37: 101-107.

Brinkman, R., A. G. Jongmans \& R. Miedema, 1977. Problem hydromorphic soils in north-east Thailand. 1. Environment and soil morphology. Neth. J. agric. Sci. 25 (2): 108-125.

Brinkman, R., 1977. Problem hydromorphic soils in north-east Thailand. 2. Physical and chemical aspects, mineralogy and genesis. Neth. J. agric. Sci. 25 (3): 170-181.

Eelaart, A. L. J. van den, 1972. Climate and crops in Thailand. Report SSR-96, Appendix 2. Land Development Department, Ministry of National Development, Bangkok.

Garrels, R. M. \& F. T. Mackenzie, 1971. Evolution of sedimentary rocks. Norton, New York, 397 pp.

Kawaguchi, K. \& K. Kyuma, 1969. Lowland rice soils in Thailand. Reports on research in S. E. Asia. Natural Science Series N-4. Centre for S.E. Asian Studies, Kyoto University, $270 \mathrm{pp}$.

Kovda, V. A., C. van den Berg \& R. M. Hagan (Ed.), 1973. Irrigation, drainage and salinity. An international source book. Hutchinson, FAO/Unesco; ISBN 0091022606; 510 pp. (Draft ed. 1967. FAO/Unesco.)

Robinson, R. A. \& R. H. Stokes, 1968. Electrolyte solutions, 2nd revised ed. Butterworths, London, $571 \mathrm{pp}$.

Sinanuwong, S. \& Y. Takaya, 1974a. Saline soils in north-east Thailand. Their possible origin as deduced from field evidence. S.E. Asian Stud. 12 (1): 105-120.

Sinanuwong, S. \& Y. Takaya, 1974b. Distribution of saline soils in the Khorat Basin of Thailand. Preliminary findings. S.E. Asian Stud. 12 (3): 365-382.

Takaya, Y., 1974. Salinity in north-east Thailand. Report of Investigation. Committee for Coordination of Investigation of the Lower Mekong Basin. Mimeo, 67 pp., cross-sections.

U S B R, 1971. Pa Mong Project Phase II. Reconnaissance Report, Appendix 1; Land Resources. U.S. Bureau of Reclamation, Bangkok.

Vlek, P. L. G., Th. J. M. Blom, J. Beek \& W. L. Lindsay, 1974. Determination of the solubility product of various iron hydroxides and jarosite by the chelation method. Proc. Soil Sci. Soc. Am. 38: 429-432.

Wernstedt, F. L., 1972. World climatic data. Climatic Data Press, P.O.B. 413, Lemont, Pa. 16851, USA, $523 \mathrm{pp}$. 